\title{
Dinamika Pengambilan Keputusan dan Perkembangan Jiwa Wirausaha pada Mahasiswa
}

\author{
Aning Az Zahra, Aftina Nurul Husna, Ahmad Liana Amrul Haq \\ Prodi Psikologi, Fakultas Psikologi dan Humaniora, Universitas Muhammadiyah Magelang, Indonesia \\ e-mail: aning.az@ummgl.ac.id
}

\begin{abstract}
This study aims to describe the dynamics of entrepreneurial decision making and the development of entrepreneurial spirit in students who are self-employed. The researcher used phenomenology to understand the psychological dynamics in students who are self-employed. The results of the study are starting from the subject decision making of entrepreneurship is related to several factors, namely internal and external factors. Internal factors related to the desire to be independent to meet needs, want to help, like challenges and seek freedom. External factors related to family and other people. This research found that an entrepreneur must have a strong commitment and consistency towards his business. An entrepreneur should also have good interpersonal skills, this is important for building relationships. Even so, the entrepreneurial spirit in students still needs to be improved, especially on commitment, consistency, and decision making.
\end{abstract}

Keywords: decision making, developmental, entrepreneurship, student

\begin{abstract}
Abstrak
Penelitian ini bertujuan untuk mengetahui gambaran mengenai dinamika pengambilan keputusan berwirausaha dan perkembangan jiwa berwirausaha pada mahasiswa yang berwirausaha. Peneliti menggunakan pendekatan fenomenologi untuk memahami dinamika psikologis dari mahasiswa yang berwirausaha. Hasil dalam penelitian ini adalah dimulai dari pengambilan keputusan subjek berwirausaha yang terkait beberapa faktor yaitu faktor internal dan eksternal. Faktor internal terkait dengan keinginan mandiri untuk memenuhi kebutuhan, ingin menolong, suka tantangan dan mencari kebebasan. Faktor ekternal terkait dengan keluarga dan orang lain. Penelitian ini menemukan bahwa seorang wirausaha harus memiliki komitmen dan konsistensi yang kuat terhadap usahanya. Seorang wirausaha juga sebaiknya memiliki kemampuan interpersonal yang baik karena hal ini penting untuk membangun relasi. Meskipun begitu jiwa kewirausahaan pada mahasiswa perlu dikembangkan terutama pada komitmen, konsistensi, dan kematangan pengambilan keputusan.
\end{abstract}

Kata Kunci: pengambilan keputusan, perkembangan, kewirausahaan, mahasiswa

\section{Pendahuluan}

Penelitian-penelitian tentang jiwa kewirausahaan perlu dikembangkan guna memahami jiwa kewirausahaan. Penelitian mengenai kewirausahaan penting karena memengaruhi terhadap rencana bisnis. Jiwa atau karakter kewirausahaan adalah karakter yang harus dimiliki oleh wirausaha (Helmi, 2009). Penelitian mengenai entrepreneurship mulai berkembang, beberapa diantaranya yaitu kepribadian Big Five dan status berwirausaha oleh Zhao dan Seibert (2006) melakukan kajian terkait dengan perbedaan kepribadian antara pengusaha dan manajer. Hasil penelitian tersebut adalah terdapat perbedaan kepribadian antara pengusaha dan manajer, pengusaha memiliki nilai yang lebih tinggi pada ketaatan dan pengalaman, sedangkan untuk ketekunan pengusaha memiliki nilai yang lebih rendah (Zhao \& Seibert, 2006).

Ahmetoglu (2014) melakukan studi tentang kepribadian wirausaha terkait dengan kerangka kerja baru dan membangun riset serta praktik kewirausahaan (Ahmetoglu, 2014). Rosmiati, Junias, dan Munawar (2015) meneliti tentang sikap, motivasi, dan minat berwirausaha pada 
mahasiswa. Dalam penelitiannya mendapatkan hasil bahwa minat dan motivasi tidak berpengaruh secara signifikan pada minat wirausaha.

Kajian dari Primandaru (2017) terkait faktor-faktor yang berpengaruh terhadap minat wirausaha pada mahasiswa. Hasil penelitian tersebut adalah adanya pengaruh internal yaitu locus of control dan social support terhadap minat berwirausaha mahasiswa, kemudian ada pengaruh locus of control terhadap need for achievement mahasiswa dan yang terakhir terdapat pengaruh need for achievement terhadap minat berwirausaha mahasiswa (Primandaru, 2017). Apabila mencermati beberapa penelitian di atas belum ada penelitian terkait dengan dinamika pengambilan keputusan dan perkembangan jiwa wirausaha pada mahasiswa.

Berdasarkan latar belakang di atas peneliti ingin meneliti mengenai dinamika pengambilan keputusan dan perkembangan karakter atau jiwa kewirausahaan mahasiswa yang Berwirausaha. Sebagaimana kita ketahui bahwa sebagian besar mahasiswa hanya berkuliah namun ada pula yang sambil bekerja sebagai karyawan. Disisi lain ada beberapa mahasiswa yang tetap berkuliah namun juga memilih untuk menjalani wirausaha. Ia tidak memilih untuk bekerja menjadi karyawan namun lebih senang untuk membangun usaha meskipun dari hal yang kecil dan berkomitmen untuk tetap lulus kuliah. Perkembangan jiwa wirausaha pada mahasiswa diteliti untuk mengetahui faktor apa yang memengaruhi jiwa kewirausahaan berkembang. Gambaran mengenai jiwa/ karakter kewirausahaan juga akan dibahas dalam penelitian ini.

\section{Jiwa Kewirausahaan}

Wirausaha sering digunakan sebagai sinonim dengan kewirausahaan. Kami mendefinisikan kewirausahaan sebagai memiliki ambisi untuk tumbuh atau berinovasi (Bengtsson, Sanandaji, \& Johannesson, 2012). Entrepreneurship merujuk kepada jiwa kewirausahaan yang mendekati pada sifat-sifat atau karakter psikologis yang harus dimiliki oleh seorang wirausahawan (Helmi, 2009). Cantillon dalam Helmi (2009) menegaskan bawa seorang wirausahawan harus berani mengambil risiko (Helmi, 2009). Pengambilan risiko ini terkait dengan ketidakpastian (Helmi, 2009). Disisi lain terkait dengan karakter wirausahawan ada karakter yang menjembatani antara ilmu dan pasar. Karakter yang menjembatani ilmu dan pasar tersebut adalah inovasi (Helmi, 2009). Selanjutnya hal lain yang harus dimiliki oleh wirausahawan yaitu kreativitas (Helmi, 2009). Menurut Hisrich dan Grachev's (dalam Frese, 2009), seseorang yang berwirausaha harus dapat mengetaui dirinya terkait kelemahan dan kelebihan dirinya sehingga ia mampu mengelola dirinya.

Freese (2009) mengatakan bahwa seorang wirausaha yang sukses, ketika terkena masalah pun tidak melupakan tujuannya dan tetap berusaha untuk meraih tujuan tersebut. Lumpkin dan Dess (dalam Freese, 2009) menerangkan bahwa karakter wirausahawan yang sukses yaitu: otonomi, inovasi, pengambilan risiko, agresivitas komersial, dan keaktifan. Orientasi kewirausahaan berhubungan dengan konsep kita tentang performa aktif. Otonomi berarti mengarahkan diri saat mengejar peluang. Orang otonom bertindak secara independen dan membuat keputusan sekalipun ada kendala. Hal ini jelas merupakan konsep yang terkait dengan konsep kinerja aktif yang dikembangkan di atas. Inovasi mengacu pada pengembangan gagasan baru (produk, layanan, dan proses). Meski inovasi tidak sama dengan self starting, ada hubungan antara kedua konsep ini. Gagasan baru merupakan aspek penting untuk memulai diri, karena untuk memulai sendiri adalah kebalikan dari meniru apa yang sedang dilakukan orang lain. Pengambilan risiko terhadap ketidakpastian. Agresivitas kompetitif adalah mampu untuk memasuki pasar yang sama 
dan mencoba mengungguli pesaing seseorang. Orang yang proaktif mengambil inisiatif untuk secara aktif mengeksploitasi peluang pasar (Frese, 2009). Tujuan, selfefficacy, dan visi yang dikomunikasikan memiliki efek langsung pada pertumbuhan usaha, dan faktor-faktor ini memediasi efek gairah, keuletan, dan keterampilan sumber daya baru pada pertumbuhan berikutnya. Selanjutnya, visi dan self-efficacy yang dikomunikasikan terkait dengan tujuan, adapun keuletan berkaitan dengan keterampilan sumber daya baru (Baum \& Locke, 2004).

Berdasarkan penjabaran di atas maka dapat disimpulkan bahwa jiwa kewirausahaan mencakup pengambilan risiko, inovasi, kreativitas, agresivitas kompetitif, otonom atau bertindak secara independen, serta keahlian dalam mencari peluang.

\section{Faktor - Faktor yang Memengaruhi Entrepreneurship}

Zhao dan Seibert (2006) menemukan bahwa ada hubungan antara status kepribadian dan status kewirausahaan. Ngoc dan Huu (2016) menyatakan lingkungan eksternal dan kelayakan yang dirasakan adalah variabel independen yang secara signifikan memengaruhi persepsi positif terhadap kewirausahaan dan memberikan dampak positif terhadap niat kewirausahaan. Di sisi lain, kelayakan dan sifat pribadi yang dirasakan secara signifikan memengaruhi persepsi negatif terhadap kewiraswastaan dan memberikan efek yang negatif terhadap niat kewirausahaan. Farouk, Ikram, dan Sami (2014) menemukan bahwa motivasi, pengalaman kerja dan pengajaran memiliki dampak yang signifikan terhadap entrepreneurship. Crasrud dan Brannback (2011) menjelaskan bahwa motivasi entrepreneurial adalah mekanisme penjelasan yang penting untuk berbagai perilaku kewirausahaan. Crasrud dan Brannback melakukan kajian dimana motivasi itu dapat memengaruhi niat dan perilaku selanjutnya. Kebutuhan akan prestasi ditemukan berhubungan positif dengan ketekunan kewirausahaan (Wu, Matthews, \& Dagher, 2010). Utami dan Istiqaroh (2014) dalam hasil penelitiannya mengatakan bahwa faktor sosialdemografis (jenis kelamin, pekerjaan orang tua dan pengalaman kewirausahaan) tidak berpengaruh terhadap niat kewirausahaan siswa. Faktor kontekstual (dukungan akademis, dukungan sosial, dan dukungan lingkungan bisnis) berpengaruh terhadap niat wirausaha siswa. Secara parsial, variabel pendukung akademik tidak berpengaruh signifikan terhadap niat wirausaha siswa.

Sarwoko (2011) yang mengkaji tentang kajian empiris entrepreneur intention pada mahasiswa mendapatkan hasil norma subjektif dan efikasi diri berdampak positif bagi intensi berwirausaha selain itu intensi berwirausaha semakin tinggi ketika subjek memiliki keluarga yang berwirausaha.

Berdasarkan pemaparan di atas dapat disimpulkan bahwa factor-faktor yang memengaruhi entrepreneurship yaitu faktor individu terkait dengan kepribadian, pengalaman, dan motivasi. Sedangkan faktor dari luar individu yaitu faktor lingkungan dan pembelajaran.

\section{Perkembangan Jiwa Kewirausahaan}

Obschonka dan Silbereisen (2012) dalam penelitiannya yang membahas tentang wirausahawan ditinjau dari segi perkembangan mengatakan bahwa jiwa kewirausahaan dipengaruhi oleh perkembangan manusia. Ada dua titik sadar dalam pembangunan manusia terkait dengan kesuksesan berwirausaha yaitu kesetaraan (berbagai titik awal dalam pengembangan dapat menghasilkan hasil yang sama) dan multifinitas yaitu titik awal yang sama dapat menghasilkan hasil perkembangan yang berbeda. Perkembangan tersebut disasarkan pada perkembangan biologis (misalnya, pengaturan genetik, temperamen, ciri kepribadian) dan peluang serta kendala ekologis (misalnya, merangsang 
lingkungan awal, interaksi parenting, dan rekan kerja). Selain itu cara beradaptasi atau karakteristik adaptasi juga memengaruhi perkembangan jiwa kewirausahaan. Karakteristik ini terkait dengan kompetensi awal dan motivasi. Karakteristik awal misalnya kepemimpinan serta kemampuan komersial, sedangkan motivasi terkait dengan self-efficacy, self esteem, values, tujuan, aspirasi, dan harapan (Obschonka \& Silbereisen, 2012).

Perkembangan jiwa kewirausahaan tidak terlepas dari jiwa dan pengalaman seseorang. Pengalaman awal memengaruhi kewirausahaan selanjutnya. Pengalaman awal yang terkait dengan keberhasilan dan prestasi akan berhubungan dengan jiwa kewirausahaan pada masa dewasa (Obschonka, Andersson, Silbereisen, \& Sverke, 2013).

\section{Karakter Wirausaha}

Ketika berbicara mengenai jiwa kewirausahaan maka merujuk pada karakter atau sifat yang harus dimiliki oleh wirausahawan (Helmi, 2009) oleh karena itu dalam memahami jiwa kewirausahaan sebaiknya mengacu kepada lima karakter wirausaha.

\section{Motivasi berprestasi}

Dalam hal ini motivasi sangat penting dalam meraih kesuksesan. Seseorang yang memiliki motivasi berprestasi menyukai pekerjaan yang menantang. Pekerjaan yang menantang menuntun untuk mengasah kemampuan dan kinerja yang lebih besar. Di negara berkembang motivasi pengusaha relatif kurang terutama dalam pembangunan yang berkelanjutan atas usahanya terutama untuk jangka panjang dan kesuksesan dalam wirausaha (Stefanovic, Prokic, \& Rankovic, 2010). Pengusaha yang sukses memiliki motivasi berprestasi yang tinggi (Brandstätter, 2011).

\section{Self-efficacy (kepercayaan diri)}

Berdasarkan penelitian dari Mcgee, Peterson, Mueller, dan Sequeira (2009) menyarankan bahwa sebagai seorang wirausaha sebaiknya meningkatkan kepercayaan dirinya. hal ini penting dalam pengambilan peluang. Terlebih karena banyaknya wirausaha baru yang muncul dan memiliki kepercayaan diri dalam kemampuan untuk mengambil peluang dan memanfaatkan peluang tersebut (Mcgee, Peterson, Mueller, \& Sequeira, 2009). Selfefficacy berhubungan dengan pengambilan risiko. Kecenderungan mengambil risiko memengaruhi self-efficacy secara signifikan, kecenderungan mengambil risiko memengaruhi sikap berwirausaha secara signifikan, norma subjektif tidak memengaruhi intensi berwirausaha secara signifikan (norma subjektif sebagai faktor eksternal tidak memiliki kontribusi dalam mendorong minat mahasiswa untuk berwirausaha, mahasiswa lebih terdorong oleh aspek internal seperti kemampuan diri dan sikap dalam mengevaluasi kegiatan berwirausaha), dan self-efficacy memengaruhi intensi berwirausaha secara signifikan (Budi, Dan, Wijaya, \& Mdp, 2012). Sarwoko (2011) menunjukkan bahwa intensi berwirausaha dipengaruhi oleh norma subjektif dan efikasi diri, dimana pengaruhnya positif, semakin tinggi dukungan pada mahasiswa, semakin tinggi rasa percaya diri dan kematangan mental, maka semakin tinggi pula niat berwirausaha.

\section{Kemandirian (otonomi)}

Otonomi atau kemandirian merupakan hal yang penting bagi orientasi dalam berwirausaha (Lumpkin, Cogliser \& Schneider, 2009). Otonomi dibutuhkan wirausaha untuk mencapai keberhasilan. Otonomi mengacu pada kemampuan untuk bekerja secara mandiri, membuat keputusan, dan mengambil tindakan yang bertujuan menghadirkan konsep bisnis atau visi dan mewujudkannya (Lumpkin dkk., 2009).

\section{Innovativeness (Inovasi)}

Inovasi merupakan penentu dari kinerja wirausaha, kegiatan inovasi penting dilakukan guna keberhasilan dalam berwirausaha (Hult, Hurley, \& Knight, 
2004). Kreativitas dan inovasi adalah hal yang fundamental dalam menciptakan performa kerja yang bagus (Amrullah, Tae, Ramdani, Irawan, \& Prakoso, 2018; Ramdani, Prakoso, Amrullah, Tae, \& Indra, 2018). Kreativitas wirausaha merupakan faktor yang penting dalam melakukan inovasi (Marcati, Guido, \& Peluso, 2008). Inovasi terkait dengan keterbukaan seseorang terhadap kebaruan dan kecenderungan untuk menjadi yang pertama mengadopsi kebaruan tersebut (Marcati dkk., 2008). Seorang wirausaha harus inovatif. Hal ini disebabkan inovasi merupakan hal yang memengaruhi performance dalam berbisnis (Hult dkk., 2004).

\section{Pengambilan risiko}

Seorang pengusaha lebih rentan terhadap risiko dibandingkan dengan yang tidak berwirausaha (MacKo \& Tyszka, 2009). Pengambilan risiko merupakan proses mengambil peluang untuk hasil yang belum pasti (Chen, Su, \& Wu, 2012). Pengusaha dengan kebutuhan tinggi akan prestasi dan yang telah menerima pendidikan tinggi lebih bersedia mengambil risiko daripada pengusaha dengan kebutuhan akan prestasi rendah dan yang belum mendapatkan pendidikan tinggi (Chen dkk., 2012). Pengusaha menunjukkan toleransi risiko yang lebih tinggi daripada pekerja penuh waktu lainnya dan juga anggota part-time yang dipekerjakan dan menganggur (Antonites \& Wordsworth, 2009).

Dalam model evaluasi peluang, Zimmerer dan Scarborough (dalam Antonites \& Wordsworth, 2009) mendeskripsikan beberapa risiko yang mungkin dihadapi oleh seorang pengusaha yaitu risiko waktu, investasi, teknis, kompetitif, serta toleransi stres dan resiliensi.

Risiko waktu. Risiko ini memerlukan implikasi waktu untuk mengambil ide baru melalui tahap pengembangan produk sampai dapat dianggap benar untuk pasar.
Risiko investasi. Ini termasuk biaya pendirian usaha baru, dengan kata lain, apakah pengusaha memiliki akses ke modal yang cukup yang memungkinkan usaha untuk bertahan hidup sampai menjadi lembaga wirausaha.

Risiko teknis. Semua aspek teknis yang terkait dengan proses pengembangan produk dipertimbangkan, dan produk akhir harus memenuhi standar kualitas teknis yang ditetapkan.

Risiko kompetitif. Ada kemungkinan bahwa pesaing dapat menawarkan produk yang sama atau sebanding di pasar, sementara tingkat keberhasilan pesaing di pasar yang sebanding juga merupakan indikasi risiko (Antonites \& Wordsworth, 2009).

Toleransi Stres dan Resiliensi. Terkait dengan toleransi terhadap stres, pengusaha memiliki toleransi terhadap stres yang lebih besar rentangnya dibandingkan orang yang tidak berwirausaha. Pengusaha memiliki toleransi terhadap stres yang lebih besar rentangnya dibandingkan pekerja penuh waktu dan juga anggota part-time yang dipekerjakan dan menganggur (Antonites \& Wordsworth, 2009). Tingkat ketahanan kewirausahaan mungkin tidak hanya tergantung pada karakteristik internal atau pribadi, tetapi juga pada faktor struktural dan eksternal pengusaha (karakteristik pribadi), perusahaan (struktur dan strategi), konteks (lingkungan mikro atau makro), dan peristiwa kegagalan (Hedner, Abouzeedan, \& Klofsten, 2017).

\section{Dinamika}

Menurut Kamus Besar Bahasa Indonesia (KBBI), dinamika merupakan gerak atau kekuatan yang terus-menerus dan menimbulkan perubahan (https://kbbi. web.id/). Pada penelitian ini dinamika akan disandingkan dengan pengambilan keputusan. 


\section{Pengambilan Keputusan}

Pengambilan keputusan dalam lingkungan ketidakpastian dan ketidaktepatan untuk masalah dunia nyata adalah sebuah tugas yang rumit (Avrachenkov \& Sanchez, 2002). Seseorang mengambil suatu keputusan tidak hanya memerhitungkan aspek rasional dan kepastian saja namun ada unsur ketidakpastian. Hal ini dibahas dalam prospek teori oleh Kahneman dan Tversky (1979). Dalam pengambilan keputusan ada istilah untung dan rugi. Ketika seseorang dihadapkan dengan kerugian yang pasti dan kerugian yang tidak pasti ia akan cenderung untuk memilih kerugian yang tidak pasti dengan harapan masih ada kemungkinan baginya untuk mendapatkan keuntungan dan menanggulangi kemungkinan rugi (Kahneman \& Tversky, 1979a). Berbanding terbalik apabila dihadapkan dengan kepastian akan keuntungan dan ketidakpastian akan keuntungan seseorang akan cenderung memilih kepastian keuntungan (Kahneman \& Tversky, 1979a). Pada pengambilan keputusan terhadap suatu ketidakpastian cenderung akan menimbukan risiko-risiko. Kahneman dan Tvesky (1979) kemudian membagi menjadi 3 tipe pengambil risiko yaitu: 1) Risk aversion, merupakan individu yang tidak menyukai risiko. Individu ini sangat mengutamakan keamanan. Ia lebih suka memilih keuntungan tanpa risiko; 2) Risk neutral merupakan individu yang bersedia untuk menerima risiko namun kurang berani mengambil risiko tinggi. Ia cenderung mengambil risiko yang sedang yang tidak terlalu merugikannya; dan 3) Risk seeking merupakan individu yang menyukai risiko. Ia berani mengambil risiko yang besar.

Kahneman \& Tvesky kemudian mengembangkan teorinya menjadi teori prospek kumulatif terkait dengan pengambilan risiko. Hal ini berlaku untuk ketidakpastian yang menghasilkan kesimpulan, yaitu: keengganan mengambil risiko untuk sebuah keuntungan, mencari risiko untuk keuntungan, memilih risiko untuk keuntungan dan keengganan mengambil risiko untuk kemungkinan yang rendah (Tversky \& Kahneman, 1992).

\section{Faktor-Faktor yang Memengaruhi Keputusan Mahasiswa Berwirausaha}

Faktor internal mahasiswa memiliki usaha mandiri didasarkan atas berani mengambil risiko, locus of control, motivasi memiliki pendapatan sendiri, kebutuhan akan kebebasan, dan ide kreatif. Faktor eksternal yang mendorong mahasiswa memiliki usaha mandiri adalah: pengaruh role model, dukungan keluarga dan teman, kesempatan, kepuasan menjalani hidup, dan pendidikan. Keputusan mahasiswa memiliki usaha mandiri didasarkan oleh intuisi, pengalaman, fakta yang terjadi di lapangan, wewenang, dan rasional. Beberapa faktor utama yang dapat membangkitkan minat wirausaha pada mahasiswa dapat dikelompokkan menjadi empat faktor, yaitu: pribadi (internal), universitas, eksternal, dan informasi (Utami \& Istiqaroh, 2014). Faktor Sosio-demografi (jenis kelamin, pekerjaan orang tua dan pengalaman kewirausahaan) tidak berpengaruh pada niat kewirausahaan. Faktor kontekstual (dukungan akademis, dukungan sosial, dan dukungan lingkungan bisnis) memengaruhi niat kewirausahaan. Secara parsial, variabel dukungan akademik tidak secara signifikan memengaruhi niat kewirausahaan (Utami \& Istiqaroh, 2014).

Faktor penghambat terbesar dalam berwirausaha adalah kegagalan usaha, dan faktor pendukung terbesar mahasiswa berwirausaha adalah orang tua (Irawati, 2017). Wijaya, Nurhadi, dan Kuncoro (2015) dalam penelitiannya mengatakan peran yang bermakna dari self-efficacy dalam mendorong minat mahasiswa berwirausaha atau semakin tinggi selfefficacy mahasiswa, maka semakin tinggi intensi berwirausaha mahasiswa. Faktorfaktor yang mendukung proses pengambil- 
an keputusan dalam menentukan karier antara lain: 1) memahami diri sendiri, 2) memiliki disiplin yang tinggi, 3) memiliki kepercayaan diri, 4) komitmen untuk berwirausaha, 5) didukung oleh keluarga dan memiliki riwayat keluarga sebagai pengusaha, 6) jaringan bisnis yang luas, 7) kemampuan dalam menyediakan barang, 8) kemampuan dalam memahami pasar, 9) kemampuan manajerial, 10) kemampuan untuk mempromosikan, 11) kemampuan untuk berinovasi, serta 12) kemampuan untuk mengelola keuangan. Sedangkan faktor penghambat meliputi: 1) kurangnya pengetahuan tentang kewirausahaan, 2) kurangnya kemampuan untuk menentukan pemasok, serta 3) kurangnya kemampuan pengadaan modal. Ismawati (2014) menyebutkan tiga faktor yang memengaruhi wirausaha yaitu minat bisnis, dorongan keluarga/ teman, dan modal usaha.

\section{Metode Penelitian}

Metode penelitian menggunakan metode kualitatif dengan pendekatan Fenomenologi (Ramdani, 2017). Teknik pengumpulan data menggunakan observasi, wawancara dan dokumentasi. Wawancara menggunakan wawancara semi terstruktur, yang mana peneliti membuat pedoman wawancara namun apabila ada data yang harus digali secara lebih mendalam maka peneliti akan menanyakannya. Teknik analisis penelitian menggunakan teknik analisis konten.

Sumber data yang digunakan dalam penelitian ini menggunakan cara crosscheck. Peneliti melakukan crosscheck dari informan pelaku dalam hal ini mahasiswa yang berwirausaha dan informan tahu yaitu orang terdekat partisipan, observasi keseharian subjek termasuk ketika subjek berjualan, cara subjek bekerja, dan kehidupan subjek sehari-hari. Peneliti juga melakukan dokumentasi produk subjek dan kegiatan subjek ketika berwirausaha.
Partisipan dalam penelitian ini berjumlah empat orang. Pemilihan partisipan dilakukan melalui prosedur purposive sampling yang memiliki karakteristik sebagai mahasiswa yang berwirausaha, dengan pengalaman 5-7 tahun dalam menggeluti profesi berwirausaha.

Pada penelitian ini peran peneliti sebagai instrumen utama dalam proses penelitian (Ramdani, 2017). Sebagai peneliti dituntut untuk mampu membangun rapport yang baik dengan partisipan penelitian. Hal ini dilakukan agar peneliti lebih mudah mendapatkan data dan partisipan mampu lebih terbuka dengan peneliti. Pada penelitian ini peneliti terlibat langsung dalam pengambilan data, observasi, dokumentasi, dan analisis data. Disisi lain peneliti tidak ikut terlibat secara langsung terkait dengan kehidupan seharihari partisipan dalam berwirausaha.

Validitas penelitian dilakukan melalui triangulasi data kepada kerabat atau orangorang terdekat partisipan. Setelah menganalisis peneliti juga melakukan pengecekan ulang kepada partisipan tentang kebenaran analisis yang dilakukan oleh peneliti.

\section{Hasil Penelitian dan Pembahasan}

\section{Hasil Penelitian}

\section{Partisipan FB}

Perjalanan wirausaha partisipan FB diawali oleh adanya ketidaknyamanan ketika bekerja menjadi karyawan. FB merasa tertekan dan ada keinginan untuk bebas. FB menemukan peluang berwirausaha yaitu pergi ke rumah pelanggan-pelanggan yang tadinya berlangganan di tempatnya bekerja. Pelanggan-pelanggan tersebut mulai berkurang kemudian FB mencoba untuk mencari pekerjaan sampingan yaitu berjualan es. Kesibukan FB kemudian membuatnya berhenti berjualan es dan hanya berjualan pada bulan ramadhan. 
Tabel 1

Profil Partisipan

\begin{tabular}{|c|c|c|c|}
\hline $\begin{array}{c}\text { Nama } \\
\text { (Inisial) }\end{array}$ & Usia & $\begin{array}{c}\text { Lama } \\
\text { Berwira } \\
\text {-usaha }\end{array}$ & $\begin{array}{c}\text { Usaha yang pernah } \\
\text { digeluti }\end{array}$ \\
\hline FB & 25 & 7 tahun & $\begin{array}{l}\text { Pijat, berjualan es } \\
\text { buah, jahit } \\
\text { (bedcover custom), } \\
\text { berjualan sempol }\end{array}$ \\
\hline NL & 21 & 5 tahun & $\begin{array}{l}\text { Berjualan pernak- } \\
\text { pernik, souvenir, } \\
\text { pop-up dan } \\
\text { dekorasi BO } \\
\text { (birthday } \\
\text { organizer) }\end{array}$ \\
\hline NA & 26 & 7 tahun & $\begin{array}{l}\text { Berjualan jersey, } \\
\text { sepatu olahraga, } \\
\text { produksi jersey }\end{array}$ \\
\hline BR & 26 & 6 tahun & $\begin{array}{l}\text { Jual asesoris mobil } \\
\text { antik, jual motor } \\
\text { dan mobil antik } \\
\text { (bekas), EO/WO }\end{array}$ \\
\hline
\end{tabular}

Partisipan FB kemudian menemukan peluang lain yaitu menjahit atau menjual bed cover, bantal, sprey dan lain-lain sesuai dengan permintaan pelanggan. Ternyata menjahit juga memerlukan modal yang banyak dan waktu yang banyak sehingga FB merasa rugi dan akhirnya berhenti. Meskipun rugi namun ia tetap memutuskan untuk berwirausaha. Hal ini disebabkan FB sudah merasa senang berwirausaha. FB kemudian melihat sempol (sempol merupakan jenis jajanan dengan bahan baku tepung terigu, tepung kanji, dan ayam) di tempat tinggalnya dan menemukan peluang karena ketika itu sempol belum banyak dikenal di daerah Yogyakarta. Hingga saat ini FB mengembangkan usaha sempol dan menambah variasi lainnya disamping berjualan sempol. Alasan FB berjualan sempol yaitu modalnya yang tidak terlalu banyak namun mendapatkan untung yang dinilai cukup.

\section{Partisipan NL}

Perjalanan wirausaha dimulai ketika partisipan NL bersekolah di SMA namun ia malas untuk melanjutkan kuliah. Saudara NL kemudian memberikan pandangan untuk membuat pop-up. NL kemudian belajar tentang pop-up dan berkesimpulan bahwa usaha tersebut bisa dijalaninya. Keputusan berwirausaha NL sebenarnya sudah terbentuk sejak SMP karena ia sudah memulai mencoba berjualan beberapa produk namun akhirnya berhenti. Hal-hal yang memengaruhi NL berwirausaha karena ia bukan termasuk orang yang suka terikat. Wirausaha ini bisa dikerjakan sambil berkuliah, dan dengan wirausaha NL berkeinginan untuk bisa membantu orang lain. Usaha ini juga merupakan hal yang ia senangi. Dalam pengambilan keputusan NL memperhitungkan modal yang ia miliki dan lebih suka mengambil risiko yang kecil meskipun keuntungannya juga kecil.

\section{Partisipan NA}

Awal mula partisipan NA berwirausaha yaitu menjual jersey. NA mengaku bahwa ia menyukai bola. NA awalnya mengambil jersey di tempat orang lain kemudian melihat peluang lain yaitu ia menawarkan kepada mahasiswa angkatannya yang ingin membuat seragam sepak bola. NA menerima pesanan seragam sepak bola dan footsal di kampusnya. Tantangan dan hambatan yang dihadapi yaitu terkait dengan kepuasan pelanggan. NA pernah mengecewakan pelanggan yang merupakan temannya sendiri. NA juga pernah mengalami kerugian namun tidak menyurutkan keinginannya untuk terus berwirausaha. NA kemudian mulai membuat brosur untuk menawarkan pembuatan seragam sepak bola. Ketika itu NA masih memasukkan ke penjahit langganannya. 
Tabel 2

Pengambilan Keputusan Berwirausaha

\begin{tabular}{ll}
\hline Nama & \multicolumn{1}{c}{ Proses Pengambilan Keputusan Berwirausaha } \\
\hline FB $\quad \begin{array}{l}\text { Pernah menjadi karyawan } \rightarrow \text { merasa tidak nyaman dan tidak bebas, merasa tertekan } \rightarrow \\
\text { mencoba berwirausaha } \rightarrow \text { menemukan kenyamanan dalam wirausaha, dengan berwirausaha } \\
\text { dapat mengembangkan diri dan menolong atau memberdayakan orang lain } \rightarrow \text { mantap } \\
\text { berwirausaha }\end{array}$ \\
NL $\quad \begin{array}{l}\text { Sejak SMP sudah beberapa kali berjualan namun berhenti } \rightarrow \text { saat SMA berjualan pernak- } \\
\text { pernik } \rightarrow \text { memiliki hobi membuat kerajinan tangan } \rightarrow \text { saat kuliah memiliki keinginan untuk } \\
\text { memenuhi kebutuhan sendiri } \rightarrow \text { tidak mau merepotkan orang tua } \rightarrow \text { ingin bebas berkreasi } \\
\text { menyalurkan hobi kerajinan } \rightarrow \text { melihat peluang dan merasa nyaman } \rightarrow \text { berwirausaha karena } \\
\text { dengan wirausaha dapat membantu orang lain }\end{array}$ \\
NA $\begin{array}{l}\text { Menyukai bola } \rightarrow \text { mulai berjualan baju bola } \rightarrow \text { melihat peluang demi peluang, menyukai } \\
\text { tantangan, dan tidak terlalu suka diatur } \rightarrow \text { terus berjuang hingga memiliki percetakan dan } \\
\text { produksi kaos sendiri, memiliki karyawan dan dapat membantu orang lain membuatnya } \\
\text { semakin mantap berwirausaha }\end{array}$ \\
$\begin{array}{l}\text { Hobi dengan mobil antik dan mengikuti komunitas } \rightarrow \text { melihat peluang untuk berjualan } \\
\text { aksesori } \rightarrow \text { merasakan bahwa wirausaha adalah hal yang menantang dan dengan berwirausaha } \\
\text { bebas mengatur sesuai dengan kemauan sehingga semakin mantap untuk memutuskan } \\
\text { berwirausaha }\end{array}$ \\
BR
\end{tabular}

NA juga mulai untuk menawarkan melalui instagram. Karena banyaknya pesanan, NA mulai memberanikan diri untuk mengajak temannya yang memiliki kemampuan desain untuk mendesain baju. Kemudian NA juga memberanikan diri merekrut karyawan untuk menjahit. NA menggunakan modal yang diperoleh dari tabungan sendiri dan meminjam dari orang tua. Seiring berjalannya waktu saat ini NA sudah memiliki alat print dan sablon sendiri. NA juga sudah memiliki karyawan sebanyak 17 orang serta memiliki langganan toko-toko penjual jersey. Orang yang menjadi contoh model bagi NA dalam berwirausaha adalah ayahnya sendiri. Ayah NA merupakan pengusaha di bidang property. NA mengatakan meskipun ayahnya merupakan seorang pengusaha namun ayahnya tidak pernah menyuruh atau meminta dirinya untuk menjadi pengusaha. Hal ini dibuktikan NA ketika ia memutuskan untuk kuliah di Program Studi Pendidikan Olahraga, ayahnya mendukung penuh. Selama berkuliah NA merasa bahwa ia membutuhkan wadah untuk berkreasi dan membutuhkan kebebasan serta keinginan untuk mandiri. Hal ini yang membuat NA terus berusaha untuk berwirausaha meski harus mengundur waktu lulus.

\section{Partisipan BR}

Awal partisipan BR berwirausaha yaitu karena ia sering diajak bergabung dengan komunitas ayahnya yaitu komunitas mobil off road, kemudian BR mulai melihat peluang untuk menjual barang-barang touring seperti baju, celana, dan peralatan lainnya. BR merasa jualannya tidak begitu ramai. BR kemudian ikut bergabung dengan komunitas mobil dan motor antik atau klasik. Awalnya BR hanya menjual pernak-pernik motor atau mobil melalui online. Adapun barang yang ia jual yaitu spion, gantungan mobil, dan lain-lain. Kemudian BR mulai membuka lapak ketika ada event. Seiring berjalannya waku ia mulai menjual ban mobil dan berjualan mobil bekas serta motor bekas. 
Usaha BR mulai berkembang hingga sekarang. Ia mulai mengikuti komunitaskomunitas lain untuk mengembangkan usahanya. Saat ini ia sudah mampu memperbaiki mobil atau motor sendiri (bengkel) kemudian ia jual. Menurutnya seorang pengusaha itu harus mampu bersosialisasi dengan baik dan tidak pelit serta gemar membantu. Hal tersebut yang ia terapkan sehingga usahanya semakin lancar. Selain komitmen dalam berwirausaha, BR mengatakan bahwa usahanya tidak mudah bahkan ia harus mengorbankan untuk menunda kelulusannya.

Berdasarkan tabel 2 dapat dijabarkan bahwa keputusan berwirausaha sebagian partisipan awalnya disebabkan ingin memenuhi kebutuhan-kebutuhan pribadinya. Disisi lain apabila dicermati keputusan berwirausaha terkait pula dengan bagaimana memaknai wirausaha tersebut dan keinginan-keinginan para partisipan penelitian. Partisipan memilih berwirausaha karena merasa bahwa berwirausaha merupakan jawaban atas keinginan mereka untuk bebas mengatur diri mereka baik dari segi waktu, finansial, serta kebebasan untuk berkreasi. Disisi lain keinginan untuk menolong dan membuka lapangan pekerjaan juga merupakan keinginan sebagian besar partisipan. Melalui wirausaha mereka dapat membuka lapangan pekerjaan dan mampu menolong orang-orang di sekitar mereka.

Keputusan berwirausaha pada mahasiswa berkaitan dengan kesenangan yaitu perasaan senang berwirausaha. Sebagian besar partisipan merasa senang berwirausaha karena wirausaha merupakan hal yang mereka sukai. Sebagian besar jenis wirausaha partisipan berhubungan dengan hobi yang disenangi oleh mereka. FB menyatakan bahwa berwirausaha merupakan cita-citanya, ia merasa nyaman dan suka berwirausaha meskipun usahanya berganti-ganti. Partisipan yang lain yaitu NL, BR, dan NA menekuni usaha yang merupakan hobi mereka. Berawal dari hobi kemudian mendapatkan peluang untuk berwirausaha. Melalui wirausaha partisipan mampu berekspresi dengan bebas sesuai dengan keinginan mereka.

Keputusan beriwausaha dipengaruhi oleh faktor internal dan eksternal. Faktor internal adalah keinginan-keinginan pribadi partisipan yaitu terkait dengan keinginan memenuhi kebutuhan, keinginan untuk bebas sehingga partisipan memilih untuk berwirausaha atau tidak bekerja sebagai karyawan, dan keinginan untuk menolong orang. Adapun faktor ekternal terkait dengan keadaan ekonomi, beberapa partisipan berwirausaha disebabkan kebutuhan ekonomi yang belum mencukupi. Disamping ekonomi terdapat pula faktor dukungan orang tua, sebagian besar partisipan mendapatkan dukungan dari orang tua dalam berwirausaha, baik yang bersifat materil maupun non materil.

Pada dasarnya para partisipan sudah memiliki ciri-ciri karakter wirausaha. Perkembangan jiwa kewirausahaan pada partisipan berbeda-beda. Hal ini terkait dengan beberapa faktor yaitu internal dan eksternal. Berdasarkan faktor internal, beberapa partisipan berpendapat bahwa meskipun ia berwirausaha namun tidak ingin mengabaikan kuliah sehingga dalam berwirausaha khususnya dalam mengambil risiko masih memilih yang menurut mereka aman. Disisi lain ada pula partisipan yang rela mengesampingkan kuliah dan fokus kepada usahanya. Setiap wirausaha memiliki perhitungan sendiri terhadap usahanya dan risiko yang akan diambil.

Partisipan dalam penelitian ini memiliki motivasi berprestasi yang cukup baik dalam arti mereka memiliki keberanian untuk mengambil risiko namun tetap mengukur kemampuan untuk menanggulanginya. Pada sisi kemandirian, partisipan berpendapat bahwa salah satu alasan mereka berwirausaha adalah dalam rangka usaha untuk mandiri. Melalui wirausaha mereka belajar untuk mandiri secara finansial, belajar cara mengatasi masalah, membuat keputusan dan lain-lain. 
Berkembangnya jiwa wirausaha pada partisipan berkaitan dengan sudut pandang partisipan ketika mendapatkan rintangan atau hambatan. Awalnya partisipan hampir berputus asa ketika hambatan datang, namun seiring berjalannya waktu mereka belajar dan menjadikan diri mereka berkembang hingga mereka memaknai bahwa dibalik setiap rintangan yang ada pasti terdapat peluang dan tantangan. Hambatan mereka anggap sebagai bahan untuk mereka selalu berinovasi dan mengembangkan usaha mereka.

Beberapa tantangan yang dialami para partisipan dalam berwirausaha yaitu pesaing, harga pasar, pelanggan dan pembagian waktu. Terkait dengan pesaing, tidak dapat dipungkiri bahwa salah satu tantangan dalam berwirausaha adalah pesaing. Seorang wirausaha harus mampu untuk bersaing agar usahanya tetap hidup atau bertahan. Harga pasar dan bahan seringkali membuat partisipan berpikir keras bagaimana agar produksi tetap terus berjalan dan menekan biaya produksi namun tetap menjaga kualitas. Langkanya barang yang dijual juga merupakan tantangan tersendiri bagi partisipan ketika menjalani wirausaha. Tantangan selanjutnya yaitu pelanggan, pelanggan merupakan hal yang paling penting dalam berwirausaha. Cara membuat pelanggan puas terhadap produk yang dibeli, cara membuat pelanggan kembali lagi untuk membeli barang, dan cara agar pelanggan menginformasikan atau mempromosikan produk kepada yang lain sehingga menambah pelanggan.

Tantangan selanjutnya berkaitan dengan pembagian waktu. Para partisipan merupakan mahasiswa yang memiliki tanggung jawab untuk berkuliah. Membagi waktu antara berwirausaha dan kuliah merupakan tantangan tersendiri bagi mereka. Ada beberapa partisipan yang tetap mengedepankan kuliah namun ada juga partisipan yang lebih fokus kepada wirausaha yang dirintisnya sehingga mengesampingkan lulus tepat waktu. Pada partisipan FB dan NL mereka tetap mementingkan kuliah meskipun berwirausaha. Berbeda dengan subjek NA dan BR yang rela menunda kelulusan untuk mengembangkan usahanya.

Dalam berwirausaha para partisipan mengaku tidak selalu lancar sehingga butuh jiwa yang tahan-banting dan tidak mudah menyerah. Selain itu yang sangat dibutuhkan yaitu komitmen dan konsisten untuk tetap menjalankan usaha yang dirintis. Menurut pengalaman beberapa partisipan mereka sempat berganti-ganti usaha dan tidak konsisten. Ketika sepi memilih untuk tutup, hal tersebut yang membuat usaha tidak maju dan cenderung gulung tikar. Melalui pengalaman tersebut para partisipan belajar bahwa dalam berwirausaha harus ada komitmen dan konsistensi yang kuat terhadap usaha yang sedang dikembangkan.

Adapun hal yang masih dianggap kurang oleh partisipan, berkaitan dengan disiplin dan komitmen dalam menggunakan uang. Dalam mengambil keputusan yang berkaitan dengan penggunaan uang partisipan mengatakan belum matang. Mereka sering menggunakan uang untuk hal-hal yang tidak terencana dan kurang penting. Selain itu dalam hal otonomi, pada subjek NA masih cenderung kepada mengedepankan pendapat orang tua meskipun kurang sesuai dengan dirinya.

\section{Perkembangan jiwa wirausaha}

Pada partisipan FB jiwa kewirausahaan dibangun dalam taraf pemantapan menjadi wirausaha. FB mulai menemukan pentingnya konsistensi dalam berwirausaha melalui pengalaman mencoba usaha, kemampuan dalam menyelesaikan masalah dan daya tahan untuk mempertahankan usahanya juga semakin terasah. FB juga sudah berani mengambil risiko untuk menambah gerobak. Pola pikir FB juga mulai memberikan ruang terhadap risiko. Jika sebelumnya ketika rugi atau sepi ia langsung berganti atau langsung tutup, maka sekarang ia mulai untuk 
mempertahankan dan menganggap bahwa dibalik risiko ada peluang. Meskipun FB masih dalam batasan mengambil risiko yang lebih kecil untuk mendapat keuntungan yang lebih besar, hal yang harus diperbaiki menurutnya adalah masalah-masalah yang berhubungan dengan uang.

Partisipan NL mengaku bahwa tantangan dan risiko yang ia hadapi selama berwirausaha membuat jiwa wirausahanya berkembang, salah satunya ia menjadi lebih kreatif karena terus belajar agar dapat memenuhi kebutuhan konsumen. Selain itu NL juga mengatakan bahwa ia sekarang lebih konsisten dalam mengembangkan usahanya. NL juga menganggap hal yang ia temui seperti persaingan dalam berwirausaha adalah tantangan baginya dan membuat ia terus maju tidak seperti sebelumnya yang mana ketika ada tantangan atau mendapatkan risiko ia berhenti. Dalam pengambilan risiko partisipan lebih memilih risiko yang kecil yang penting lancar dan berjalan usahanya. Dalam pengambilan keputusan partisipan masih sering bergantung dengan orang tua.

Partisipan NA memaparkan bahwa awal mula berwirausaha pada dasarnya ia memang sudah menyenangi tantangan dan kebebasan. Menurut NA hal yang pertama harus ada ketika memulai wirausaha adalah cinta. Ia juga mengatakan bahwa jiwa kewirausahaannya berkembang termasuk kematangan mengambil keputusan, mencari peluang dan relasi, daya tahan terhadap hambatan dan konsistensi untuk mengembangkan bisnisnya. Jiwa wirausaha NA berkembang karena ia mulai berwirausaha. Ketika memulai wirausaha akan datang tantangan, hambatan, saingan, dan keinginan untuk tetap eksis di dunia wirausaha.

Pengalaman-pengalaman berwirausaha yang membuat jiwa wirausahanya berkembang. Meski demikian NA mengatakan bahwa ia masih kurang dalam hal kematangan pengambilan keputusan dan disiplin dalam mengelola uang.
Jiwa wirausaha partisipan BR berkembang ketika ia menjalani wirausaha. Tantangan, para pesaing dan cara agar tetap mempunyai pelanggan adalah hal yang membuat jiwa wirausahanya berkembang. Segala pengalaman adalah guru terbaik dari timbulnya jiwa kewirausahaan, yang paling penting dari wirausaha adalah konsisten dan disiplin. Menurut BR wirausaha memang bebas menentukan waktunya sendiri, penghasilannya sendiri namun wirausaha bisa jadi jam kerjanya lebih banyak, lebih lelah, serta harus lebih bisa mengatur waktu. Oleh karena itu disiplin, komitmen, dan konsistensi adalah hal yang penting. BR juga mengatakan bahwa wirausaha harus kreatif dan tidak mudah puas dengan pencapaian. Dulu cara berpikir BR tidak seperti sekarang, namun dengan berjalannya waktu ia mengaku lebih dapat membaca peluang, memaknai hambatan sebagai hal yang positif, dan memiliki daya juang yang lebih tinggi demi untuk mengembangkan usahanya. BR juga mengatakan bahwa ia semakin kreatif. BR menyadari bahwa ia masih kurang dalam hal komitmen. Ia sering mendahulukan bermain dengan teman-temannya dan menunda pekerjaan. Selain itu dalam hal mengatur keuangan BR mengatakan bahwa ia masih sering tidak konsisten yang mana uang yang seharusnya digunakan untuk diputar kembali namun dipakai untuk memenuhi hobinya.

\section{Pembahasan}

Faktor-faktor yang memengaruhi partisipan dalam berwirausaha hampir sama dengan teori yang disampaikan Irawati (2017) bahwa faktor yang memengaruhi seseorang berwirausaha terdiri atas faktor internal dan faktor eksternal (Irawati, 2017). Faktor internal yaitu berkaitan dengan keinginan bebas, menyukai tantangan, dan lain-lain. Sedangkan faktor eksternal yaitu terkait dengan faktor ekonomi, dukungan pihak luar, dan lainlain. Disisi lain hal yang belum dibahas dalam pustaka yaitu berkaitan dengan 
keinginan untuk membantu orang lain. Membantu orang lain dalam hal ini yaitu baik orang tua, keluarga maupun menciptakan lapangan kerja bagi orang lain.

Kahneman dan Tversky (1979) menyatakan bahwa ketika seseorang dihadapkan dengan kerugian yang pasti dan kerugian yang tidak pasti ia akan cenderung untuk memilih kerugian yang tidak pasti dengan harapan masih ada kemungkinan baginya untuk mendapatkan keuntungan dan menanggulangi kemungkinan rugi. Berbanding terbalik apabila dihadapkan dengan kepastian akan keuntungan dan ketidakpastian akan keuntungan, seseorang akan cenderung memilih kepastian keuntungan. Pada partisipan penelitian yaitu mahasiswa yang berwirausaha mereka tetap mempertimbangkan untung rugi dan lebih menekankan kepada risk neutral. Secara rasional partisipan tetap mempertimbangkan risiko terhadap sesuatu yang tidak pasti. Meskipun ada beberapa yang memilih risiko yang cukup tinggi atau risk seeking dalam arti rela mengorbankan kuliah dengan menunda kelulusan demi fokus kepada usahanya. Selain itu beberapa partisipan yang meminjam uang di bank untuk tambahan modal usaha namun mereka tetap memperkirakan risiko dan cara penanggulangannya. Bagi partisipan, pengambilan keputusan yang matang itu adalah pengambilan keputusan yang mengetahui sebab dan akibat seseorang memutuskan hal tersebut. Pada partisipan keputusan mereka untuk berwirausaha awalnya didasari pertimbangan 'yang penting memulai' namun dalam pengambilan keputusan setiap permasalahan mereka tetap mempertimbangkan akibatnya. Partisipan juga mengakui bahwa sesuatu yang tidak pasti itu merupakan tantangan bagi mereka.

Faktor penghambat terbesar dalam berwirausaha adalah kegagalan usaha dan faktor pendukung terbesar adalah orang tua (Irawati, 2017). Wijaya dkk. (2015) dalam penelitiannya mengatakan peran yang bermakna dari self efficacy dalam mendorong minat mahasiswa berwirausaha atau semakin tinggi self efficacy mahasiswa, maka semakin tinggi intensi berwirausaha mahasiswa. Sedangkan menurut Ismawati (2014) tiga faktor yang memengaruhi wirausaha yaitu minat bisnis, dorongan keluarga/ teman, dan modal usaha (Ismawati, 2014).

Pada penelitian ini kegagalan usaha bagi partisipan bukan merupakan faktor penghambat bagi partisipan untuk berwirausaha. Terdapat partisipan yang beberapa kali mencoba berbagai usaha. Ketika usaha partisipan tidak mampu bertahan di pasar dan harus menutup usahanya namun partisipan tetap berusaha untuk mencari usaha yang mampu bertahan dan bersaing di pasar. Peran kepercayaan partisipan terhadap diri sendiri turut serta dalam keputusan partisipan berwirausaha.

Seorang wirausahawan menurut para partisipan harus memiliki kepercayaan diri yang baik terutama dalam menghadapi persaingan. Kepercayaan diri merupakan hal yang sangat penting terkait dengan pengambilan keputusan dalam berwirausaha. Seorang wirausahawan boleh meminta pendapat dari orang lain ketika ingin mengambil keputusan namun tetap harus memiliki otonomi terhadap keputusannya.

Pada penelitian ini, sebelum partisipan melakukan wirausaha, partisipan sudah memiliki karakter kewirausahaan seperti otonomi, pengambilan risiko, inovatif, dan kemandirian. Dalam hal otonomi, keputusan partisipan berwirausaha merupakan gambaran otonomi yang dimiliki oleh partisipan. Partisipan memiliki keinginan untuk bebas serta mampu mengambil keputusan berwirausaha sesuai dengan keinginannya, hal tersebut menggambarkan otonomi dari partisipan. Para partisipan juga sudah memiliki karakter pengambilan risiko. Hal ini terlihat juga pada pengambilan keputusan berwirausaha dimana partisipan mengambil risiko untuk membagi antara kuliah dan berwirausaha. 
Partisipan juga memiliki motivasi berprestasi, dalam mengambil risiko partisipan tetap melihat kemampuan mereka. Karakter inovatif partisipan yaitu mereka merupakan individu-individu yang suka mencoba dan berinovasi. Partisipan juga sudah memiliki karakter kemandirian dimana mereka berkeinginan untuk mandiri secara finansial serta sudah memiliki otonomi yang mencerminkan kemandirian. Hal ini turut didukung penelitian Lumpkin dan Dess (dalam Freese, 2009) yang menerangkan bahwa karakter wirausahawan yang sukses yaitu: otonomi, inovasi, pengambilan risiko, agresivitas komersial, dan keaktifan. Karakter lainnya yaitu innovativeness (Hult dkk., 2004), toleransi terhadap stres (Antonites \& Wordsworth, 2009), kemandirian (Lumpkin dkk., 2009), self efficacy (Mcgee dkk., 2009), dan pengambilan risiko (Antonites \& Wordsworth, 2009).

Dalam hal motivasi berprestasi beberapa partisipan berusaha untuk menyeimbangkan antara kuliah dan wirausaha namun ada juga yang lebih fokus kepada usahanya. Agresivitas komersial tampaknya belum terlihat pada partisipan yang cenderung fokus pada pengembangan usaha dan memertahankan usahanya dibandingkan mencari keuntungan.

Faktor-faktor yang mendukung proses pengambilan keputusan dalam menentukan karier antara lain: 1) memahami diri sendiri, 2) memiliki disiplin yang tinggi, 3) memiliki kepercayaan diri, 4) komitmen untuk berwirausaha, 5) didukung oleh keluarga dan memiliki riwayat keluarga sebagai pengusaha, 6) jaringan bisnis yang luas, 7) kemampuan dalam menyediakan barang, 8) kemampuan dalam memahami pasar, 9) kemampuan manajerial, 10) kemampuan untuk mempromosikan, 11) kemampuan untuk berinovasi, serta 12) kemampuan untuk mengelola keuangan. Sedangkan faktor penghambat meliputi: 1) kurangnya pengetahuan tentang kewirausahaan, 2) kurangnya kemampuan untuk menentukan pemasok, dan 3) kurangnya kemampuan pengadaan modal (As, In, \& Municipality, 2016).

Dalam penelitian ini sesuai dengan teori yang dibahas bahwa dalam proses pengambilan keputusan partisipan lebih menekankan kepada memahami diri sendiri dimana mereka memiliki kebutuhan akan kebebasan. Namun terkait dengan kemampuan-kemampuan yang harus dimiliki partisipan mengakui bahwa hal tersebut akan berkembang dengan sendirinya. Awal mula partisipan memutuskan untuk berwirausaha tidak terlalu mempertimbangkan kemampuan-kemampuan yang harus dimiliki wirausaha. Seiring dengan berjalannya waktu baru kemudian kemampuan tersebut terasah dan berkembang.

Pada penelitian ini jiwa kewirausahaan berkembang seiring dengan perkembangan partisipan. Pengalaman partisipan dalam berwirausaha juga turut serta memengaruhi perkembangan kewirausahaan mereka. Dalam hal ini perkembangan jiwa usaha partisipan berbeda-beda tergantung pada dasar karakter kewirausahaan yang dimiliki serta pengalaman dalam berwirausaha. Hasil ini senada dengan yang dikatakan oleh Obschonka dan Silbereisen (2012) bahwa jiwa kewirausahaan dipengaruhi oleh perkembangan manusia. Hanya saja selain perkembangan, pengalaman dan dukungan dari lingkungan juga turut serta.

Perkembangan jiwa kewirausahaan tidak terlepas dari jiwa dan pengalaman seseorang. Pengalaman awal memengaruhi kewirausahaan selanjutnya. Pengalaman awal yang terkait dengan keberhasilan dan prestasi akan berhubungan dengan jiwa kewirausahaan pada masa dewasa (Obschonka dkk., 2013). Pada penelitian ini pengalaman akan kegagalan dan menghadapi tantangan membuat para partisipan menjadi lebih kuat dan lebih matang dalam mengambil risiko, memiliki keinginan untuk berjuang lebih keras, dan lebih matang dalam menghadapi tantangan.

Pada penelitian ini pribadi partisipan yang lebih suka kepada kebebasan ekologis 
yaitu dimana mereka dibesarkan dengan kemandirian, kompetensi awal dan motivasi. Kompetensi awal misalnya kepemimpinan serta kemampuan komersial, sedangkan motivasi terkait dengan self-efficacy, self esteem, values, tujuan, aspirasi, dan harapan. Motivasi partisipan penelitian terkait dengan selfefficacy yaitu partisipan memiliki kepercayaan diri yang cukup baik hal ini terlihat dari perilaku partisipan mempromosikan produknya dan mengunggulkan produknya juga mengatakan bahwa ia cukup yakin mampu untuk mengembangkan usahanya.

Partisipan juga memiliki nilai, tujuan, aspirasi dan harapan. Partisipan memiliki nilai tentang wirausaha. Menurut partisipan apabila seseorang bangga bekerja di tempat yang terkenal termasuk menjadi abdi negara dan menganggap bahwa seseorang yang berwirausaha merupakan pekerjaan yang dipilih terakhir ketika tidak diterima bekerja. Partisipan justru berpendapat bahwa wirausaha adalah kemandirian yang sebenarnya dan dengan berwirausaha justru kita mampu untuk memberdayakan atau menolong seseorang dengan cara membuka lapangan pekerjaan bagi mereka. Nilai ini berhubungan dengan tujuan dan harapan partisipan yaitu mampu mengembangkan usahanya termasuk mampu membantu menciptakan lapangan pekerjaan.

Partisipan sudah memiliki dasar berdasarkan hasil pengalaman awal partisipan yang memengaruhi perkembangan kewirausahaan mereka. Berdasarkan teori, pengalaman awal yang terkait dengan keberhasilan dan prestasi akan berhubungan dengan jiwa kewirausahaan pada masa dewasa. Bagi partisipan tidak hanya pengalaman awal terkait dengan keberhasilan atau prestasi saja yang memengaruhi jiwa wirausaha di masa dewasa namun juga kegagalan atau hambatan. Bagi partisipan, pengalaman yang terkait dengan hambatan atau kegagalan menjadi pelajaran yang baik untuk memperkuat jiwanya.
Dalam perjalanan partisipan berwirausaha, jiwa atau karakter kewirausahaan mereka berkembang. Dalam hal ini motivasi sangat penting untuk meraih kesuksesan. Seseorang yang memiliki motivasi berprestasi menyukai pekerjaan yang menantang. Pekerjaan yang menantang menuntun untuk mengasah kemampuan dan kinerja yang lebih besar. Dalam hal motivasi berprestasi, seiring dengan berjalannya waktu dan pengalaman, motivasi berprestasi mereka semakin baik. Partisipan semakin bersemangat untuk mengembangkan bisnisnya dan bersemangat pula dalam menghadapi tantangan, karena di setiap tantangan ada peluang dan pembelajaran untuk mereka berkembang.

Mcgee dkk. (2009) menyarankan bahwa sebagai seorang wirausaha sebaiknya meningkatkan kepercayaan dirinya. Hal ini penting dalam pengambilan peluang. Terlebih karena banyaknya wirausaha baru yang muncul dan memiliki kepercayaan diri dalam kemampuan untuk mengambil peluang dan memanfaatkan peluang tersebut.

Pada penelitian ini ditemukan bahwa partisipan semakin percaya diri untuk mempromosikan produknya, mengambil peluang, serta mengambil keputusan dalam setiap perjalanan wirausaha. Mereka semakin mandiri terutama dalam hal mengambil keputusan. Meskipun terkadang meminta pertimbangan dari orang lain namun dalam mengambil keputusan tetap dirinya sendiri yang menimbang, dalam arti tidak lantas mengikuti orang lain. Otonomi dibutuhkan wirausaha untuk mencapai keberhasilan. Otonomi mengacu pada kemampuan untuk bekerja secara mandiri, membuat keputusan, dan mengambil tindakan yang bertujuan menghadirkan konsep bisnis atau visi dan mewujudkannya (Lumpkin dkk., 2009). Melalui pengalaman, menjadikan partisipan semakin dapat mengambil keputusan secara mandiri meskipun ada partisipan yang meminta pendapat orang tua ketika hendak 
memutuskan sesuatu namun sudah berkurang dibandingkan dengan sebelum partisipan memiliki pengalaman berwirausaha.

Bagi partisipan kreativitas merupakan hal yang penting yang harus dimiliki oleh wirausaha. Pernyataan ini senada dengan penelitian Marcati dkk. (2008) yang mengatakan bahwa kreativitas penting bagi seorang wirausaha. Kreativitas penting agar pengusaha dapat bertahan dengan perubahan. Pesaing yang semakin banyak membuat wirausaha harus lebih kreatif. Kreativitas berhubungan dengan inovasi. Seorang wirausaha harus terbuka terhadap kebaruan dan partisipan pada penelitian ini terbuka dengan suatu kebaruan. Hal ini dimungkinkan karena mahasiswa termasuk ke dalam generasi muda. Inovasi merupakan sesuatu yang memengaruhi performance dalam berbisnis (Hult dkk., 2004). Semakin banyaknya pengalaman, tantangan, pesaing, dan permasalahan yang harus dihadapi membuat partisipan semakin kreatif dan inovatif. Partisipan lebih terbuka terhadap kebaruan dan berusaha menyesuaikan diri dengan kebaruan tersebut. Partisipan menyadari bahwa inovasi merupakan hal yang sangat penting dalam menghadapi dunia wirausaha.

Pengambilan risiko merupakan mengambil peluang untuk hasil yang belum pasti (Chen dkk., 2012). Pengusaha dengan kebutuhan tinggi akan prestasi dan yang telah menerima pendidikan tinggi lebih bersedia mengambil risiko daripada pengusaha dengan kebutuhan akan prestasi rendah dan yang belum mendapatkan pendidikan tinggi (Chen dkk., 2012). Pengusaha menunjukkan toleransi risiko yang lebih tinggi daripada pekerja penuh waktu lainnya dan juga anggota part-time yang dipekerjakan dan menganggur (Antonites \& Wordsworth, 2009). Pengalaman berwirausaha membuat partisipan semakin matang dalam pengambilan risiko, terutama terkait dengan pengembangan usahanya. Risiko pembagian waktu antara kuliah dan usaha, risiko rugi, dan lain-lain. Partisipan juga mulai berani mengambil risiko yang lebih dibandingkan saat partisipan baru memulai usahanya.

Terkait dengan toleransi terhadap stres, pengusaha memiliki toleransi terhadap stres yang lebih besar rentangnya dibandingkan orang yang tidak berwirausaha atau pekerja penuh waktu lainnya dan juga anggota part-time yang dipekerjakan dan menganggur (Antonites \& Wordsworth, 2009). Awal mula berwirausaha partisipan sudah memiliki toleransi terhadap stres namun seiring dengan pengalamanpengalaman mereka dalam berwirausaha partisipan menjadi lebih tahan-banting dan memiliki toleransi stres yang lebih baik juga kemampuan untuk bangkit lebih baik. Partisipan juga bisa lebih berpikir positif yaitu menemukan peluang di setiap kesulitan.

\section{Simpulan}

Simpulan penelitian ini adalah pengambilan keputusan pada mahasiswa untuk berwirausaha didasari oleh beberapa faktor yaitu faktor internal dan eksternal. Faktor internal terkait dengan keinginan mandiri untuk memenuhi kebutuhan, ingin menolong, dan mencari kebebasan. Faktor eksternal terkait dengan keluarga dan orang lain. Partisipan memaknai bahwa wirausaha merupakan sesuatu yang dapat mengakomodasi keinginan-keinginannya salah satunya terkait dengan kebebasan, kesenangan, dan keinginan untuk menolong orang lain (memberdayakan orang lain). Jiwa wirausaha mahasiswa berkembang seiring dengan pengalaman mahasiswa dalam berwirausaha terkait dengan inovasi (kreativitas), kemampuan menyelesaikan masalah, daya tahan terhadap stres, dan konsistensi dalam berwirausaha. Partisipan menemukan arti penting konsistensi dalam berwirausaha. Meskipun begitu, partisispan cenderung masih belum disiplin dan konsisten dalam mengatur keuangan dan waktu. Pada penelitian ini ditemukan bahwa seorang wirausaha harus memiliki 
komitmen dan konsistensi yang kuat terhadap usahanya. Seorang wirausaha juga sebaiknya memiliki kemampuan interpersonal yang baik karena hal ini penting untuk membangun relasi.

\section{Daftar Pustaka}

Amrullah, S., Tae, L. F., Ramdani, Z., Irawan, F. I., \& Prakoso, B. H. (2018). Studi sistematik aspek kreativitas dalam konteks pendidikan. Psympathic: Jurnal Ilmiah Psikologi, 5(2), 187-200. doi.org/10.15575/psy.v5i2.3533

Antonites, a J., \& Wordsworth, R. (2009). Risk tolerance: A perspective on entrepreneurship education. Southern African Business Review, 13(3), 69-85.

As, A. C., In, E., \& Municipality, M. (2016). Faktor pendukung dan faktor penghambat dalam supporting and inhibiting factors in deciding a career as young. 327-339.

Avrachenkov, K. E., \& Sanchez, E. (2002). Fuzzy markov chains and decisionmaking. Fuzzy Optimization and Decision Making, 1(2), 143-159. doi.org/10.1023/A:1015729400380

Baum, J. R., \& Locke, E. A. (2004). The relationship of entrepreneurial traits, skill, and motivation to subsequent venture growth. Journal of Applied Psychology, 89(4), 587-598. doi.org/10.1037/0021-9010.89.4.587

Bengtsson, O., Sanandaji, T., \& Johannesson, M. (2012). The psychology of the entrepreneur and the gender gap in entrepreneurship. IFN Working Paper, Institute of Industrial Economics, (944), 46. Diakses dari http://www.ifn.se/wfiles/wp/wp944.pdf

Brandstätter, H. (2011). Personality aspects of entrepreneurship: A look at five meta-analyses. Personality and Individual Differences, 51(3), 222-230. doi.org/10.1016/j.paid.2010.07.007

Budi, R., Dan, L., Wijaya, T., \& Mdp, S. (2012). Pengaruh pendidikan kewirausahaan terhadap minat berwirausaha mahasiswa di STIE MDP, STMIK MDP, dan STIE MUSI. Forum Bisnis dan Kewirausahaan Jurnal Ilmiah STIE MDP, 1(2), 112119.

Carsrud, A., \& Brannback, M. (2011). Entrepreneurial motivations: What do we still need to know? Journal of Small Business Management, 49(1), 926.

doi.org/10.1097/01.mcg.0000190752.4 8621.fa

Chen, S., Su, X., \& Wu, S. (2012). Need for achievement, education, and entrepreneurial risk-taking behavior. Social Behavior and Personality: An International Journal, 40(8), 13111318. doi.org/10.2224/sbp.2012.40.8.1311

Lumpkin, G. T., Cogliser, C. C., \& Schneider, D. R. (2009). Understanding and measuring autonomy: An entrepreneurial orientation perspective. Entrepreneurship Theory and Practice, 33(91), 47-69.

Farouk, A., Ikram, A., \& Sami, B. (2014). The influence of individual factors on the entrepreneurial intention. International Journal of Managing Value and Supply Chains, 5(4), 47-57. doi.org/10.5121/ijmvsc.2014.5404

Frese, M. (2009). Towards a psychology of entrepreneurship: An action theory perspective. Foundations and Trends in Entrepreneurship, 5(6), 437-496. doi.org/10.1561/0300000028

Hedner, T., Abouzeedan, A., \& Klofsten, M. (2017). Entrepreneurial resilience. Journal of Annals of Innovation \& Entrepreneurship, 2(1), 7986. doi.org/10.3402/aie.v2i1.7986

Helmi, A. F. (2009). Kewirausahaan di perguruan tinggi dalam perspektif psikologi. Buletin Psikologi, 17(2), 5765. doi.org/10.22146/bpsi.11483

Hult, G. T. M., Hurley, R. F., \& Knight, G. A. (2004). Innovativeness: Its 
antecedents and impact on business performance. 33, 429-438. doi.org/10.1016/j.indmarman.2003.08. 015

Irawati, R. (2017). Pengambilan keputusan usaha mandiri mahasiswa ditinjau dari faktor internal dan eksternal. Jurnal JIBEKA, 11(1), 58-69.

, K. (2014). Model pembuatan keputusan entrepreneurship pendahuluan ILO (International Labour Organization) dalam data statistiknya menyebutkan bahwa tingkat pengangguran Indonesia mencapai 69 persen. Salah satu cara pemberdayaan mengembangkan kreativitas kerja. 191-205.

Kahneman, D., \& Tversky, A. (1979a). Prospect theory: An analysis of decision under risk. Econometrica: Journal of the Econometric Society, 47(3), 263-291. doi.org/10.1111/j.15367150.2011.00774.X

Kahneman, D., \& Tversky, A. (1979b). Prospect theory: An analysis of decision under risk. Econometrica, 47(2), 263-292. doi.org/10.2307/1914185

MacKo, A., \& Tyszka, T. (2009). Entrepreneurship and risk taking. Applied Psychology, 58(3), 469-487. doi.org/10.1111/j.14640597.2009.00402.x

Marcati, A., Guido, G., \& Peluso, A. M. (2008). The role of SME entrepreneurs' innovativeness and personality in the adoption of innovations. Research Policy, 37(9), 1579-1590. doi.org/10.1016/j.respol.2008.06.004

Mcgee, J. E., Peterson, M., Mueller, S. L., \& Sequeira, J. M. (2009). Entrepreneurial self-efficacy: Refining the measure. Entrepreneurship: Theory and Practice, 33(4), 965-988. doi.org/10.1111/j.15406520.2009.00304.x

Ngoc, K. M., \& Hu, A. N. (2016). The factors affecting entrepreneurial intention of the students of Vietnam national university:Aa mediation analysis of perception toward entrepreneurship. Journal of Economics, Business and Management, 4(2), 104-111. doi.org/10.7763/JOEBM.2016.V4.375

Obschonka, M., Andersson, H., Silbereisen, R. K., \& Sverke, M. (2013). Rulebreaking, crime, and entrepreneurship: A replication and extension study with 37-year longitudinal data. Journal of Vocational Behavior, 83(3), 386-396. doi.org/10.1016/j.jvb.2013.06.007

Obschonka, M., \& Silbereisen, R. K. (2012). Entrepreneurship from a developmental science perspective. International Journal of Developmental Sciences, 6(3-4), 107$115 . \quad$ doi.org/10.3233/DEV-201212105

Primandaru, N. (2017). Analisis faktorfaktor yang berpengaruh pada minat berwirausaha mahasiswa. Jurnal Economia, 13(1), 68-78. DOI: 10.21831/economia.v13i1.13276

Ramdani, Z., Prakoso, B. H., Amrullah, S., Tae, L. F., \& Indra, F. (2018). Pengujian level kreativitas pada siswa berdasarkan skala kekuatan dan kebajikan karakter dan tes kreativitas verbal. Jurnal Ilmu Perilaku, 2, 107117.

Ramdani, Z. (2017). Forgiving is not only forgetting (phenomenological study on forgiveness in individual who experiences a friendship conflict). IJASOS-International E-Journal of Advances in Social Sciences. doi.org/10.18769/ijasos.366853

Rosmiati, R., Junias, D. T. S., \& Munawar, M. (2015). Sikap, motivasi, dan minat berwirausaha mahasiswa. Journal of Management and Entrepreneurship, 17(1), 21-30. doi.org/10.9744/jmk.17.1.21-30

Sarwoko, E. (2011). Kajian empiris entrepreneur intention mahasiswa. 
Jurnal Ekonomi Bisnis, 16(2), 126135.

Stefanovic, I., Prokic, S., \& Rankovic, L. (2010). Motivational and success factors of entrepreneurs: The evidence from a developing country. $\mathrm{Zb}$. rad. Ekon. fak. Rij. 28(2), 251-270.

Tversky, A., \& Kahneman, D. (1992). Advances in prospect-theorycumulative representation of uncertainty. Journal of Risk and Uncertainty, 5(4), 297-323. doi.org/Doi 10.1007/Bf00122574

Utami, S. B., \& Istiqaroh, C. R. (2014). Faktor-faktor yang berpengaruh terhadap niat berwirausaha (entrepreneurial intention): Studi pada mahasiswa universitas merdeka madiun. Ekomaks, 3(September), 1436.
Wijaya, T., Nurhadi., \& Kuncoro, A. (2015). Intensi berwirausaha mahasiswa: Perspektif pengambilan risiko. Siasat Bisnis, 19(2), 109-123.

Wu, S., Matthews, L., \& Dagher, G. K. (2010). Need for achievement, business goals, and entrepreneurial. Management Research News, 30(12), 928-941. doi.org/10.1108/01409170710833358

Zhao, H., \& Seibert, S. E. (2006). The big five personality dimensions and entrepreneurial status: A metaanalytical review. Journal of Applied Psychology, 91(2), 259-271. doi.org/10.1037/0021-9010.91.2.259 
Psympathic, Jurnal Ilmiah Psikologi Juni 2019, Vol. 6, No. 1, Hal. : 111-130 